\title{
To Hedge or Not to Hedge...That Is the Question \\ Empirical Evidence from the North American Gold Mining Industry 1996-2000
}

The Leonard N. Stern School of Business

Glucksman Institute for Research in Securities Markets

Faculty Advisor: Marti Subrahmanyam

April 10, 2002 
"Ashanti shows that even if a country is not rated AAA or AA, its commodity producers can still hedge successfully." in

- Kwame Peprah, Ghana Finance Minister, 09/26/99

"I am prepared to concede that we were reckless. We took a bet on the price of gold. We thought it would go down and we took a position." "We are ready to consider any option...and that includes the sale of all of our assets but Obuasi and Geita." ii

- Sam Jonah, CEO Ashanti Goldfields, November 1999

\section{INTRODUCTION}

The story of Ashanti Goldfields highlights the potential dangers involved in overly aggressive risk management. In this case, hedging gold price risk with futures contracts, which are marked-to-market, against gold that is buried in the ground, led to a liquidity crisis. Less than two weeks after Kwame Peprah's glowing endorsement of the firm's practices, Ashanti revealed a $\$ 570 \mathrm{~m}$ loss on its hedging, of which nearly half was owed immediately to creditors, and Ashanti's shares plunged. That story demonstrates why the debate continues in the gold mining industry as to the proper approach to hedging gold price risk. In the larger context, corporate risk management continues to deserve and to receive a great amount of attention. One need only pick up the newspaper to see a clear and present justification for active risk management. Whether it's the Enron and Andersen debacle, a rogue trader inside a large institution, or the attacks of September $11^{\text {th }}$, uncertainty is inherent in nearly any type of business activity, and no firm is completely immune to the variety of risks that can undo even the best managed firm. Hence, risk management is an integral part of management's duties, and evaluation of risk management strategies is a necessary component of the decision-making process. 
But does a firm's effort to minimize the effects of these risks add real value to the firm? Corporate finance theory dictates that shareholder wealth maximization should be the primary focus of every management decision. Therefore, corporate risk management decisions (including hedging decisions) should be driven by that objective. Presumably, firm managers actively manage risk if they believe that doing so will reduce expenses, improve cash flows, or even reduce the firm's cost of capital (e.g. by reducing default risk). On the other hand, management's desire to minimize exposure to risk could conceivably distract it from the objective function of the firm - to maximize firm value (i.e. maximize the stock price). In addition, while reducing risk should tend to protect bondholders, it might unnecessarily penalize stockholders, especially those who are already well-diversified and insulated from firm-specific risk.

This paper attempts to discover if any quantitative evidence indicates that risk management leads to sustainable benefits for firm owners. The paper examines risk management practices in the North American gold mining industry from 1996 through 2000, encompassing the hedging practices of twenty North American gold mining firms, and their respective stock return regression alphas. Peter Tufano of the Harvard Business School has published previous work related to this topic, most notably in $1996^{\mathrm{iv}}$ and $1998^{\text {—in }}$ the Journal of Finance. Professor Tufano's papers focus on identifying the factors that influence management's decision to hedge risk, and on the determinants of gold mining stock price exposures, most notably the exposure to the spot price of gold. Unlike Professor Tufano's work, this study is a search for a statistical correlation between the hedging practices of gold mining firms and their stock returns. 


\section{BACKGROUND}

\section{Why Study the North American Gold Mining Industry}

Several characteristics suggest that the North American gold mining industry is ideal for academic study. All of the firms in this industry are in the same line of business, and their product is an actively traded and volatile commodity. In addition, all of the firms in this group share a clear exposure to gold price risk. Gold mining firms typically manage their exposure to gold price risk by using a wide variety of financial instruments including forwards and futures contracts, gold loans, and options (puts and calls). Perhaps most importantly, gold mining firms disclose their risk management activities in great detail. Such disclosures show that the majority of firms in this industry use some type of hedge portfolio to manage gold price risk, and the composition of those portfolios are described in their annual reports. The 20 gold mining firms studied meet the following criteria:

- Each is publicly traded either on the New York Stock Exchange (NYSE), the American Stock Exchange (AMEX), or the Toronto Stock Exchange (TSE).

- Each identifies gold mining as a primary line of business.

- Each is headquartered in the United States or Canada.

Although there are a number of other gold mining firms in addition to the twenty selected, those firms are very small and are not actively traded on an organized exchange. In addition, many of those other firms did not produce any gold for some period between 1996 and 2000, making analysis difficult. The twenty firms included in the study account for the majority of gold mining production by North American companies, and are listed in Table 1 . 
Table 1: North American Gold Mining Companies

\begin{tabular}{lcrr}
\hline Firm & Ticker & $\begin{array}{r}\text { Recent Stock } \\
\text { Price (USD) }\end{array}$ & $\begin{array}{r}\text { 2000 Revenues } \\
\text { (millions of USD) }\end{array}$ \\
\hline Agnico-Eagle Mines LTD & AEM & $\$ 10.84$ & $\$ 67.00$ \\
\hline Barrick Gold Corporation & ABX & $\$ 17.30$ & $\$ 1,330.00$ \\
\hline Bema Gold Corporation & BGO & $\$ 0.38$ & $\$ 29.11$ \\
\hline Cambior Inc. & CBJ & $\$ 0.52$ & $\$ 199.53$ \\
\hline Canyon Resources Corp. & CAU & $\$ 1.17$ & $\$ 34.73$ \\
\hline Coeur D Alene Mines Corp. & CDE & $\$ 0.91$ & $\$ 93.17$ \\
\hline Crystallex International Corp. & KRY & $\$ 1.72$ & $\$ 21.76$ \\
\hline Dayton Mining Corporation & DAY & $\$ 0.35$ & $\$ 35.59$ \\
\hline Echo Bay Mines LTD & ECO & $\$ 0.59$ & $\$ 280.98$ \\
\hline Glamis Gold LTD & GLG & $\$ 3.99$ & $\$ 61.15$ \\
\hline Goldcorp Inc. & GG & $\$ 13.06$ & $\$ 39.24$ \\
\hline Hecla Mining Co. & HL & $\$ 1.04$ & $\$ 75.85$ \\
\hline Homestake Mining & HM & $\$ 9.05$ & $\$ 665.67$ \\
\hline Kinross Gold Corp. & KGC & $\$ 0.86$ & $\$ 288.10$ \\
\hline Meridian Gold Inc. & MDG & $\$ 11.82$ & $\$ 128.28$ \\
\hline Newmont Mining Corp & NEM & $\$ 19.69$ & $\$ 1,809.45$ \\
\hline Placer Dome Inc. & PDG & $\$ 11.77$ & $\$ 1,413.00$ \\
\hline Richmont Mines Inc. & RIC & $\$ 1.18$ & $\$ 23.05$ \\
\hline TVX Gold Inc. & TVX & $\$ 0.50$ & $\$ 161.62$ \\
\hline Vista Gold & VGZ & $\$ 0.07$ & $\$ 3.81$ \\
\hline & & & \\
\hline
\end{tabular}

Each firm's performance is strongly influenced by the price of gold (historically, gold stocks move, percentage-wise, by a factor of two or three to one with the movement in the price of gold ${ }^{\text {ii }}$; therefore hedging gold price risk is an integral part of each firm's management activity. With the exception of Goldcorp, which did not hedge any of its gold during the period, all of the firms in the survey hedge some amount of their future gold production through the use of various financial instruments, such as forward sales, gold loans and options. These instruments allow the firm to lock in a minimum price for at least a fraction of their future production. A review of annual reports shows a wide variety in the extent of hedging within the industry, which is another factor that makes this industry ideal 
for study. For example, Barrick has traditionally hedged nearly all of its near-term production, whereas Glamis Gold usually hedges less than $10 \%$ of future production.

\section{The Hedging Debate among Gold Producers}

Despite the variety of hedging practices among gold mining companies, the debate over the wisdom of hedging persists between companies with extreme positions: those that hedge, and those that do not. At one end of the spectrum, Barrick claims that their Premium Gold Sales Program “not only increases [Barrick's] revenues, it makes them more predictable and lowers risk." and adds "We continually make more money for our product simply by selling it in advance. It's like getting paid a premium to take out insurance." "iii At the other extreme, Goldcorp is quick to highlight the fact that they do not hedge any of their future gold production, and uses this fact as a sign of their disciplined financial management, claiming "Gold is money.", iiii

As illustrated by the travails of Ashanti Goldfields, hedging can certainly introduce its own set of risks. An obvious downside of hedging is the loss of profits should the price of gold rise dramatically. Firms that do not hedge their gold production (or hedge very little) have long argued that exposure to price appreciation is more important than protection against downside loss should prices fall. Those companies further claim that gold investors are naturally interested in the volatility of gold prices to enhance their returns, and this is why they invest in gold in the first place. The Ashanti case points out another problem with hedging using futures contracts. Since those instruments are marked-to-market on a daily basis against gold that is buried in the ground, a liquidity crisis can result if the price of gold increases significantly. Since it was underground, Ashanti could not sell their gold to come up with the cash needed to cover their futures positions. 
Some anecdotal evidence suggests that aggressive hedging on the part of gold producers does not maximize shareholder returns. John Hathaway, senior portfolio manager of the Tocqueville Gold Fund, insists that hedging has led to an over-supply in the market, and that this has been a prominent factor in depressing gold prices in recent years. ${ }^{\square} \mathrm{Mr}$. Hathaway's strategy for his gold fund is to avoid holding gold stocks that in his words "hedge away the upside. ${ }^{\mathrm{G}}$ The Tocqueville Gold Fund has done well since its inception in June of 1998, earning a three-year average annual return of $20.86 \%$ compared to the Philadelphia Stock Exchange Gold/Silver Index, which has earned an average annual return of $4.57 \%$ over the same period.

On the other hand, hedging provides gold producers with a minimum price for their product. That is certainly a benefit during a period when the price of gold is going down, and it consistently went down each year on an average basis between 1996 and 1999. Due to their extensive hedge portfolio, Barrick consistently received a higher average price for their gold than Goldcorp for the five years studied. Hedging may also provide a more predictable and steady cash flow stream, and may help to smooth earnings. Firms like Barrick apparently feel strongly that those benefits outweigh the risks associated with hedging. In addition, firms that hedge attempt to adjust their portfolio based on the outlook for the gold price. For example, Barrick has recently announced plans to significantly reduce the size of their hedge portfolio, due in part to the recent upward movement in the price of gold. In other words, firms that adopt at least some hedging seem to be more flexible with their position than those that condemn the practice of hedging outright. To the extent that hedging can add managerial flexibility, it may actually enhance the value of the firm. 


\section{State of the Industry}

The gold mining industry has fallen on hard times in the past few years, as the price of gold has stagnated around its lowest point since 1979. From an all-time high of over $\$ 600$ per troy ounce in 1980 (a bubble price created by the disruption of the world market for petroleum), the price of gold has steadily fallen to its current level of approximately $\$ 290$ per ounce. For the 5-year period studied, the average price of gold in 1996 was approximately $\$ 388$ per ounce, while the average price in 2000 was approximately $\$ 279$ per ounce. As a result, many gold mining firms have been forced to shut down mines that are no longer economically viable, and others have filed for Chapter 11 bankruptcy protection (including one firm in the study - Vista Gold). The challenging economics of gold mining in recent years has also led to a period of consolidation in the industry. Two of the largest producers, Barrick and Homestake, announced a merger in 2001, and Newmont just recently offered to acquire Australia's Normandy Mining Ltd. and Franco-Nevada Mining Corp. With few exceptions, the industry as a whole has under-performed the market as reflected in each firm's regression alpha. In fact, the average annualized excess return relative to the market for each of the twenty firms over the 5 -year period is $-26 \%$. 


\section{METHODOLOGY OF THE STUDY}

The methodology for this study follows four main steps. First, I examine the regression alphas (i.e. the intercept that results from regressing a firm's stock returns against the market) for the twenty gold mining firms studied, and test whether or not the mean is close to zero as one would expect. I then test the widely held belief that investors view gold firms as real options by examining the relationship between stock price volatility and returns as measured by the alpha. Next, I examine the relationship between hedging and alpha. Finally, I examine the relationship between hedging and stock price volatility.

The regression alpha provides a simple measure of performance during the period of the regression relative to the capital asset pricing model. For this study, each firm's daily and weekly returns were regressed against the S\&P 500 Index for each of the five years 1996 though 2000. In addition, each firm's daily returns were regressed against the broad Stock File Index ${ }^{\square}(\mathrm{SFI})$ from The Center for Research in Security Prices (CRSP) database. I calculate the mean alpha for each year and across all five years, and determine a $95 \%$ confidence interval to test the hypothesis that the average alpha is close to zero

Those who are opposed to hedging argue, among other things, that because investors view gold firms as real options, any reduction in cash flow volatility through hedging will necessarily make the firm less valuable (i.e. volatility is a key determinant of option value, including so-called real options). If investors indeed view gold firms as real options, then one would expect a correlation between volatility and alpha. Although it would be most useful to use the volatility of cash flows for this test, I was not able to collect this data, so I use the

\footnotetext{
${ }^{1}$ The CRSP Stock File Index includes over 8,000 securities.

${ }^{2}$ All statistical analysis that was performed for the study was done using MINITAB statistical software.
} 


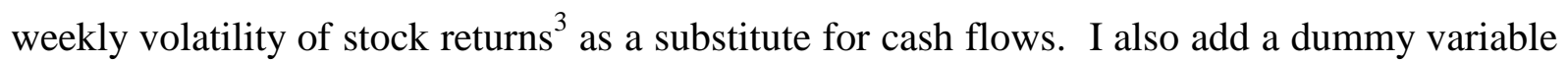
for each year (1996-1999) in order to pool the results across time. The hypothesis is that alpha will increase with stock price volatility.

In order to determine if hedging practices have an impact on shareholder value, I search for statistical significance between a firm's alpha and the extent of hedging employed by the firm. The extent of risk management for each firm is determined by calculating the effective number of ounces of gold that each firm has effectively hedged, or sold forward. Each of the firms studied report on an annual basis their hedging portfolio of gold-related instruments. Although quarterly data would be more useful for this study, I was only able to find annual data for each firm. For firms that hold options, an effective portfolio delta must be calculated. This portfolio delta relates their options position to an equivalent number of ounces of gold that have effectively been hedged. To illustrate, a hypothetical example of the hedge portfolio and delta calculation for one firm at the end of 1996 is presented in Table 2.

Table 2: Calculating the Equivalent Hedge Position for a Firm at the end of 1996

\begin{tabular}{|c|c|c|c|c|c|c|}
\hline & \multicolumn{2}{|c|}{1997} & \multicolumn{2}{|c|}{1998} & \multicolumn{2}{|c|}{1999} \\
\hline & Ounces & $\begin{array}{l}\text { Price } \\
\text { (USD) }\end{array}$ & Ounces & $\begin{array}{r}\text { Price } \\
\text { (USD) }\end{array}$ & Ounces & $\begin{array}{r}\text { Price } \\
\text { (USD) }\end{array}$ \\
\hline Forward sales & 1,000 & 350 & 5,000 & 360 & 10,000 & 370 \\
\hline Puts (purchased) & 5,000 & 350 & 1,000 & 360 & 500 & 370 \\
\hline Calls (sold) & 10,000 & 415 & 5,000 & 420 & 1,000 & 425 \\
\hline Total: & 16,000 & & 11,000 & & 11,500 & \\
\hline Grand Total: & 38,500 & & & & & \\
\hline \multicolumn{7}{|c|}{ Calculation of Portfolio Delta } \\
\hline Position & & & Oun & & Delta & Ounces \\
\hline Forward sales (all) & & & 16 & & -1 & $-16,000$ \\
\hline
\end{tabular}

\footnotetext{
${ }^{3}$ The standard deviation of weekly returns for each calendar year was calculated by taking the weekly closing prices for each firm from the Yahoo Finance website.

${ }^{4}$ The delta for future and forward positions equals -1 . The delta for an options position is calculated using the Black-Scholes model for option pricing which uses as its inputs the maturity of the option, the risk-free rate, the gold lease rate, the spot price of gold, the strike price of the option, and the annualized volatility of gold prices. For this study, the risk-free rate used is $5.1 \%$ (average 10-year T-note), the annual gold lease rate is $1.42 \%$, and the standard deviation of annual gold returns is $30.13 \%$ (average over the past 30 years). In addition, the spot price is taken as the average price of gold for the year. The average price of gold for the years 1996, 1997, 1998, 1999, and 2000 is 387.81, 331.02, 294.24, 278.98, and 279.11 respectively. All options are assumed to be European in style, which means that they can be exercised only on the last day of the period.
} 
Put options maturing in 1997

Put options maturing in 1998

Put options maturing in 1999

Call options maturing in 1997

Call options maturing in 1998

Call options maturing in 1999

Total Equivalent Ounces in Hedge Position

\begin{tabular}{rrr}
5,000 & -.270 & $-1,350$ \\
1,000 & -.288 & -288 \\
500 & -.287 & -144 \\
10,000 & -.519 & $-5,190$ \\
5,000 & -.579 & $-2,895$ \\
1,000 & -.617 & -617 \\
\hline
\end{tabular}

The top panel of the above table illustrates the typical presentation of a firm's gold derivative portfolio as reported in their annual report. The bottom panel, which is typically not presented in the annual report, calculates the equivalent number of ounces of gold (in this case 26,484 ) that the firm would need to hold in a replicating portfolio to their hedged position. In order to create a multiple that can be compared across firms of different size, this amount is then divided by the firm's anticipated three-year future production, as well as by the firm's stock of Proven and Probable Reserves

Compiling the hedging data for twenty firms over five years was accomplished by sifting through the footnotes of 100 annual reports. Several of the firms studied use a broad variety of instruments to hedge the various forms of risk that they face. For example, some of the firms that are also involved in silver mining use silver-based derivatives in addition to gold derivatives in their hedge portfolios. Other firms use various currency and interest rate hedging instruments as well. For this study, I have only included each firm's gold derivative portfolios, since this is the primary method by which each firm hedges gold price risk.

One would expect the hedging factor to be a problematic causal variable based on the measurement process described above. That is, one should assume that the error in the hedging factor will cause a disturbance in the dependent variable (i.e. alpha), and will therefore bias the results. This fact requires one to use a two-stage least squares (2SLS)

\footnotetext{
${ }^{5}$ Three-year future production is estimated based on the predicted production for the following year, which is usually reported by the firm, as well as management's discussion of future prospects. The stock of proven and probable reserves is usually reported in each firm's annual report.
} 


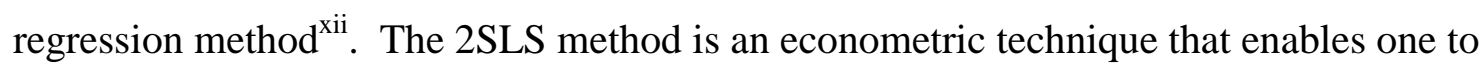

"clean up" the offending variable (i.e. the hedging factor) by performing the regression in two stages.

In the first stage, I regress the hedging factor against a number of instruments (independent variables) in order to create a regression equation that can be used to generate "expected" hedging factors. Nineteen instruments are included in stage one ${ }^{\natural}$ these include the cash balance of the firm , the balance of current assets, operating income before depreciation (EBITDA), the cost of goods sold (COGS), the balance of long term debt, long term debt per common equity, the current portion of long term debt, the debt due in one year, the balance of convertible debt, the balance of subordinated debt, the balance of debt notes, total debentures, other long term debt, net income, total current executive compensation, total

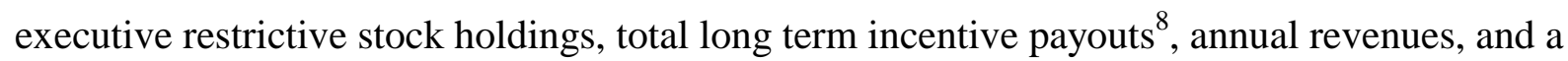
dummy variable that identifies if the firm is engaged in another business besides gold mining $\square$ (e.g. silver mining, or mining for other minerals).

In stage two, I regress alpha against the new expected hedging variable and the yearly dummy variables. If one believes that hedging reduces volatility, then one would expect hedging to be negatively correlated with the alpha.

In the final step, I explicitly examine the effect of hedging on volatility by regressing the weekly volatility of stock returns against the hedging variable and yearly dummy variables. In this case, the hypothesis is that hedging will reduce volatility.

\footnotetext{
${ }^{6}$ Nineteen instruments were required to push the adjusted $\mathrm{R}^{2}$ of the regression up to $90 \%$.

${ }^{7}$ Annual financial statement data was taken from the COMPUSTAT database.

${ }^{8}$ All data related to executive compensation was taken from the COMPUSTAT database. For the study, I took the sum of all amounts paid to a firm's executives. The COMPUSTAT database did not include data for all of the firms in the study, but any data that was available was used.

${ }^{9}$ Determined from information presented on each firm's website and in their annual reports.
} 


\section{FINDINGS}

The resulting regression alphas for each firm are presented below in Table 3.

Table 3: Gold Mining Firm Regression Alphas ${ }^{10}$

\begin{tabular}{|c|c|c|c|c|c|c|}
\hline \multirow{2}{*}{ Firm } & & \multicolumn{5}{|c|}{ Year } \\
\hline & & 1996 & 1997 & 1998 & 1999 & 2000 \\
\hline \multirow{3}{*}{ Agnico-Eagle Mines LTD } & S\&P Daily & 0.05 & -0.32 & -0.05 & 0.30 & -0.02 \\
\hline & S\&P Weekly & 0.18 & -1.90 & -0.26 & 1.49 & -0.16 \\
\hline & SFI Daily ${ }^{11]}$ & 0.09 & -0.33 & -0.02 & 0.31 & -0.03 \\
\hline \multirow{3}{*}{ Barrick Gold Corporation } & S\&P Daily & 0.03 & -0.15 & 0.03 & 0.01 & 0.00 \\
\hline & S\&P Weekly & -0.07 & -0.72 & -0.04 & 0.10 & 0.01 \\
\hline & SFI Daily & 0.05 & -0.18 & 0.04 & 0.01 & -0.01 \\
\hline \multirow{3}{*}{ Bema Gold Corporation } & S\&P Daily & 0.52 & -0.26 & -0.29 & 0.16 & 0.00 \\
\hline & S\&P Weekly & 2.53 & -1.18 & -1.68 & 0.17 & -1.44 \\
\hline & SFI Daily & 0.55 & -0.32 & -0.23 & 0.15 & 0.04 \\
\hline \multirow{3}{*}{ Cambior Inc. } & S\&P Daily & 0.12 & -0.32 & -0.05 & -0.26 & -0.07 \\
\hline & S\&P Weekly & 0.61 & -1.54 & -0.51 & -1.12 & -1.92 \\
\hline & SFI Daily & 0.14 & -0.39 & -0.02 & -0.26 & -0.14 \\
\hline \multirow{3}{*}{ Canyon Resources Corp. } & S\&P Daily & 0.04 & -0.21 & -0.03 & 1.09 & 1.36 \\
\hline & S\&P Weekly & 0.20 & -1.41 & -1.47 & 5.34 & 5.93 \\
\hline & SFI Daily & 0.12 & -0.22 & 0.05 & 1.14 & 0.31 \\
\hline \multirow{3}{*}{ Coeur D Alene Mines Corp. } & S\&P Daily & -0.01 & -0.18 & -0.20 & -0.06 & -0.24 \\
\hline & S\&P Weekly & -0.17 & -0.91 & -1.13 & -0.02 & -1.55 \\
\hline & SFI Daily & 0.01 & -0.18 & -0.16 & -0.03 & -0.24 \\
\hline \multirow{3}{*}{ Crystallex International Corp. } & S\&P Daily & & 0.71 & -0.24 & 0.71 & 0.21 \\
\hline & S\&P Weekly & $\mathrm{N} / \mathrm{A}^{42}$ & 2.50 & -0.78 & 2.99 & 0.88 \\
\hline & SFI Daily & & 0.06 & -0.24 & 0.81 & 0.13 \\
\hline \multirow{3}{*}{ Dayton Mining Corporation } & S\&P Daily & 0.17 & -0.44 & -0.36 & 1.09 & 4.15 \\
\hline & S\&P Weekly & 0.56 & -2.15 & -2.88 & 0.18 & 15.81 \\
\hline & SFI Daily & 0.25 & -0.43 & -0.35 & 1.04 & -0.49 \\
\hline \multirow{3}{*}{ Echo Bay Mines LTD } & S\&P Daily & -0.19 & -0.29 & -0.02 & 0.00 & -0.30 \\
\hline & S\&P Weekly & -0.97 & -1.47 & 0.44 & -0.28 & -2.13 \\
\hline & SFI Daily & -0.13 & -0.33 & 0.02 & 0.00 & -0.24 \\
\hline \multirow{3}{*}{ Glamis Gold LTD } & S\&P Daily & 0.10 & -0.26 & -0.17 & 0.12 & 0.07 \\
\hline & S\&P Weekly & 0.20 & -1.10 & -1.05 & 5.62 & 0.22 \\
\hline & SFI Daily & 0.11 & -0.25 & -0.14 & 0.10 & 0.03 \\
\hline \multirow{3}{*}{ Goldcorp Inc. } & S\&P Daily & -0.15 & -0.23 & 0.22 & 0.05 & 0.08 \\
\hline & S\&P Weekly & -0.37 & -0.92 & 0.86 & 0.32 & 0.30 \\
\hline & SFI Daily & 0.16 & -0.27 & 0.23 & 0.04 & 0.06 \\
\hline \multirow{3}{*}{ Hecla Mining Co. } & S\&P Daily & -0.10 & 0.04 & -0.04 & -0.25 & -0.22 \\
\hline & S\&P Weekly & -0.70 & 0.19 & -0.47 & -1.21 & -1.79 \\
\hline & SFI Daily & -0.07 & 0.00 & -0.03 & -0.23 & -0.21 \\
\hline \multirow{3}{*}{ Homestake Mining } & S\&P Daily & -0.05 & -0.17 & 0.06 & 0.00 & -0.20 \\
\hline & S\&P Weekly & -0.38 & -0.90 & 0.24 & 0.03 & -0.90 \\
\hline & SFI Daily & 0.00 & -0.19 & 0.07 & 0.01 & -0.20 \\
\hline \multirow{3}{*}{ Kinross Gold Corp. } & S\&P Daily & -0.11 & -0.28 & -0.10 & 0.02 & -0.26 \\
\hline & S\&P Weekly & -0.46 & -1.45 & -0.59 & 0.16 & -1.99 \\
\hline & SFI Daily & -0.02 & -0.26 & -0.04 & 0.01 & -0.29 \\
\hline \multirow[t]{2}{*}{ Meridian Gold Inc. } & S\&P Daily & 0.06 & -0.11 & 0.41 & 0.16 & 0.11 \\
\hline & S\&P Weekly & 0.39 & -0.58 & 2.58 & 0.61 & 0.42 \\
\hline
\end{tabular}

${ }^{10}$ All alphas are presented in percentage terms as opposed to decimal terms (e.g. 0.5\% as opposed to 0.005 ).

${ }^{11}$ The broad Stock File Index from the Center for Research in Security Prices (CRSP) database.

${ }^{12}$ Crystallex was not publicly traded in 1996. 


\begin{tabular}{l|c|c|c|c|c|c}
\hline & SFI Daily & 0.03 & -0.09 & 0.42 & 0.15 & 0.09 \\
\hline \multirow{3}{*}{ Newmont Mining Corp } & S\&P Daily & -0.01 & -0.18 & -0.11 & 0.22 & -0.05 \\
& S\&P Weekly & -0.18 & -0.92 & -0.58 & 1.14 & -0.23 \\
& SFI Daily & 0.02 & -0.21 & -0.09 & 0.22 & -0.10 \\
\hline \multirow{3}{*}{ Placer Dome Inc. } & S\&P Daily & -0.05 & -0.22 & -0.02 & 0.04 & 0.03 \\
& S\&P Weekly & -0.37 & -1.10 & -0.07 & 0.32 & 0.09 \\
& SFI Daily & -0.03 & -0.24 & -0.01 & 0.05 & 0.01 \\
\hline \multirow{3}{*}{ Richmont Mines Inc. } & S\&P Daily & & -0.19 & 0.08 & -0.11 & 0.02 \\
& S\&P Weekly & N/A 13 & -0.88 & 0.15 & -0.51 & -0.56 \\
\hline \multirow{3}{*}{ TVX Gold Inc. } & SFI Daily & & -0.22 & 0.07 & -0.02 & 0.01 \\
\hline \multirow{3}{*}{ Vista Gold } & S\&P Daily & 0.03 & -0.28 & -0.13 & -0.16 & 1.20 \\
& S\&P Weekly & 0.13 & -1.57 & -0.77 & -0.72 & 4.91 \\
& SFI Daily & 0.08 & -0.28 & -0.10 & -0.16 & -0.06 \\
\hline
\end{tabular}

The mean alphas, as well as $95 \%$ confidence intervals for the means, for each of the

five years are presented below in Table 4. Confidence intervals that include zero are highlighted in bold.

Table 4: Mean Alphas for Gold Firms 1996 - 2000

\begin{tabular}{|c|c|c|c|c|c|c|}
\hline & 1996 & 1997 & 1998 & 1999 & 2000 & $\begin{array}{c}\text { 5-Year } \\
\text { Average }\end{array}$ \\
\hline $\begin{array}{l}\text { S\&P Daily Mean } \\
95 \% \text { Con. Interval }\end{array}$ & $\begin{array}{c}0.022 \\
(-0.056,0.099)\end{array}$ & $\begin{array}{c}-0.176 \\
(-0.283,-0.068)\end{array}$ & $\begin{array}{c}-0.024 \\
(-0.125,0.077)\end{array}$ & $\begin{array}{c}0.197 \\
(0.007,0.387)\end{array}$ & $\begin{array}{c}0.330 \\
(-0.141,0.800)\end{array}$ & $\begin{array}{c}0.070 \\
(-0.052,0.197)\end{array}$ \\
\hline $\begin{array}{l}\text { S\&P Week Mean } \\
95 \% \text { Con. Interval }\end{array}$ & $\begin{array}{c}0.052 \\
(-0.319,0.424)\end{array}$ & $\begin{array}{c}-0.996 \\
(-1.454,-0.538)\end{array}$ & $\begin{array}{c}-0.398 \\
(-0.908,0.112)\end{array}$ & $\begin{array}{c}0.746 \\
(-0.125,1.617)\end{array}$ & $\begin{array}{c}0.777 \\
(-1.143,2.696)\end{array}$ & $\begin{array}{c}0.036 \\
(-0.381,0.470)\end{array}$ \\
\hline $\begin{array}{l}\text { SFI Daily Mean } \\
95 \% \text { Con. Interval }\end{array}$ & $\begin{array}{c}0.086 \\
(0.012,0.161)\end{array}$ & $\begin{array}{c}-0.230 \\
(-0.285,-0.175)\end{array}$ & $\begin{array}{c}0.078 \\
(-0.157,0.313)\end{array}$ & $\begin{array}{c}0.207 \\
(0.016,0.398)\end{array}$ & $\begin{array}{c}-0.022 \\
(-0.152,0.108)\end{array}$ & $\begin{array}{c}0.024 \\
(-0.070,0.118)\end{array}$ \\
\hline
\end{tabular}

As indicated by the confidence intervals in Table 4, the mean alphas for the twenty firms in the sample over the five years are consistently close to zero. The remainder of the study examines the differences between alphas of the individual firms (i.e. why are some firms' alphas higher than others).

In order to test the view that investors view gold firms as real options, I regressed the Stock File Index alphas $\frac{14}{4}$ against the weekly volatility of stock returns $\frac{5}{6}$ The results of this

\footnotetext{
${ }^{13}$ Richmont was not publicly traded during 1996.

${ }^{14}$ The broad Stock File Index was used rather than the S\&P because of the consistently higher $\mathrm{R}^{2}$, s for regressions against the stock file index. I did perform similar regressions against the S\&P 500, and found similar results, although these are not presented here.

${ }^{15}$ Weekly volatility represents the standard deviation of weekly returns for the calendar year.
} 
regression are shown below. The standard error for each coefficient is presented in parentheses under each term, with bold indicating statistical significance $\frac{6}{6}$

Regression Coefficients Where the Dependent Variable is SFI Daily Alpha

\begin{tabular}{c|cccccc}
\hline $\begin{array}{c}\text { Adjusted } \\
\mathbf{R}^{2}(\%)\end{array}$ & Constant & $\begin{array}{c}\text { Weekly } \\
\text { Volatility }\end{array}$ & $\begin{array}{c}\text { Year 1 } \\
\text { Dummy }\end{array}$ & $\begin{array}{c}\text { Year 2 } \\
\text { Dummy }\end{array}$ & $\begin{array}{c}\text { Year 3 } \\
\text { Dummy }\end{array}$ & $\begin{array}{c}\text { Year 4 } \\
\text { Dummy }\end{array}$ \\
\hline \multirow{2}{*}{59.8} & -0.37135 & 3.5705 & 0.25947 & -0.10955 & -0.03703 & 0.18392 \\
& $(\mathbf{0 . 0 6 0 5 1 )}$ & $(\mathbf{0 . 3 4 4 5 )}$ & $(\mathbf{0 . 0 7 4 4 2})$ & $(0.07163)$ & $(0.07220)$ & $(\mathbf{0 . 0 7 1 1 3})$ \\
\hline
\end{tabular}

Based on the high T-statistic of weekly volatility (10.36) in the regression above, it appears that gold firms do behave like real options when it comes to volatility. This supports the hypothesis that a reduction in volatility (either in cash flows or stock returns) will make the firm less valuable. The next step is to explicitly examine the effects of hedging on alpha.

Each of the hedging factors for the twenty firms over the five-year period was determined using the delta calculation method described in the previous section. These are presented below in Table 5.

Table 5: Gold Hedge Portfolios as a Fraction of Production and Reserves ${ }^{17}$

\begin{tabular}{|c|c|c|c|c|c|c|}
\hline \multirow{2}{*}{ Firm } & & \multicolumn{5}{|c|}{ Year } \\
\hline & & 1996 & 1997 & 1998 & 1999 & 2000 \\
\hline \multirow{2}{*}{ Agnico-Eagle Mines LTD 区iii } & Prod. & 0.0000 & 0.0000 & 0.0000 & 0.2991 & 0.2717 \\
\hline & PPR & 0.0000 & 0.0000 & 0.0000 & 0.0748 & 0.0709 \\
\hline \multirow{2}{*}{ Barrick Gold Corporation iiv } & Prod. & 0.7444 & 1.0100 & 1.0874 & 1.0072 & 1.2273 \\
\hline & PPR & 0.1311 & 0.2008 & 0.2428 & 0.2089 & 0.2727 \\
\hline \multirow{2}{*}{ Bema Gold Corporation 四 } & Prod. & 0.4267 & 0.4228 & 0.2119 & 0.4768 & 0.6011 \\
\hline & PPR & 0.0646 & 0.0166 & 0.0491 & 0.0163 & 0.1765 \\
\hline \multirow{2}{*}{ Cambior Inc. } & Prod. & 0.1209 & 0.7811 & 1.2255 & 1.1316 & 0.9598 \\
\hline & PPR & 0.0434 & 0.2968 & 0.5232 & 0.3913 & 0.6019 \\
\hline \multirow{2}{*}{ Canyon Resources Corp. vviil } & Prod. & 1.1452 & 0.7325 & 0.3333 & 0.1623 & 0.0171 \\
\hline & PPR & 0.3600 & 0.2334 & 0.1433 & 0.0061 & 0.0009 \\
\hline \multirow{2}{*}{ Coeur D Alene Mines Corp.viii } & Prod. & 0.1715 & 0.1944 & 0.2813 & 0.3354 & 0.4215 \\
\hline & PPR & 0.0431 & 0.0565 & 0.0482 & 0.0619 & 0.0439 \\
\hline \multirow{2}{*}{ Crystallex International Corp. } & Prod. & 0.0000 & 0.0000 & 0.5700 & 0.6158 & 0.2991 \\
\hline & PPR & 0.0000 & 0.0000 & 0.4771 & $N / A^{[18]}$ & $N / A^{[19]}$ \\
\hline \multirow{2}{*}{ Dayton Mining Corporation区 } & Prod. & 0.3174 & 0.1132 & 0.1209 & 0.0643 & 0.0000 \\
\hline & PPR & 0.0822 & 0.0403 & 0.0580 & 0.0598 & 0.0000 \\
\hline
\end{tabular}

\footnotetext{
${ }^{16}$ Statistical significance for each factor corresponds to a T-statistic greater than 2.0 or less than -2.0 . Each Tstatistic is simply the coefficient divided by the standard error for that coefficient.

${ }^{17}$ Presented as the number of ounces of gold that are hedged divided by the number of ounces of gold that are expected to be produced over the next three years (Prod.), and by the number of ounces of gold in the firm's stock of proven and probable reserves (PPR).

${ }^{18}$ Crystallex did not report their stock of PPR in the 1999 annual report.

${ }^{19}$ Crystallex did not report their stock of PPR in the 2000 annual report.
} 


\begin{tabular}{|c|c|c|c|c|c|c|}
\hline Echo Bay Mines LTD 凶x & $\begin{array}{l}\text { Prod. } \\
\text { PPR }\end{array}$ & $\begin{array}{l}0.1859 \\
0.0455 \\
\end{array}$ & $\begin{array}{l}0.6145 \\
0.1257 \\
\end{array}$ & $\begin{array}{l}0.5446 \\
0.1117 \\
\end{array}$ & $\begin{array}{l}0.1548 \\
0.0596\end{array}$ & $\begin{array}{l}0.1173 \\
0.0449 \\
\end{array}$ \\
\hline Glamis Gold LTD殴 & $\begin{array}{l}\text { Prod. } \\
\text { PPR }\end{array}$ & $\begin{array}{l}0.0160 \\
0.0034\end{array}$ & $\begin{array}{l}0.0239 \\
0.0039\end{array}$ & $\begin{array}{l}0.0098 \\
0.0020\end{array}$ & $\begin{array}{l}0.1531 \\
0.0327\end{array}$ & $\begin{array}{l}0.0419 \\
0.0121\end{array}$ \\
\hline 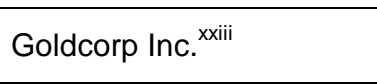 & $\begin{array}{l}\text { Prod. } \\
\text { PPR }\end{array}$ & $\begin{array}{l}0.0000 \\
0.0000\end{array}$ & $\begin{array}{l}0.0000 \\
0.0000\end{array}$ & $\begin{array}{l}0.0000 \\
0.0000\end{array}$ & $\begin{array}{l}0.0000 \\
0.0000\end{array}$ & $\begin{array}{l}0.0000 \\
0.0000\end{array}$ \\
\hline Hecla Mining Co. $\frac{\text { 区xil }}{2}$ & $\begin{array}{l}\text { Prod. } \\
\text { PPR }\end{array}$ & $\begin{array}{l}0.1057 \\
0.1056\end{array}$ & $\begin{array}{l}0.0515 \\
0.0277\end{array}$ & $\begin{array}{l}0.0250 \\
0.0116\end{array}$ & $\begin{array}{l}0.7899 \\
0.3939\end{array}$ & $\begin{array}{l}0.5314 \\
0.2994\end{array}$ \\
\hline Homestake Mining & $\begin{array}{l}\text { Prod. } \\
\text { PPR }\end{array}$ & $\begin{array}{l}0.1046 \\
0.0333\end{array}$ & $\begin{array}{l}0.1469 \\
0.0570\end{array}$ & $\begin{array}{l}0.1943 \\
0.0697\end{array}$ & $\begin{array}{l}0.1265 \\
0.0445\end{array}$ & $\begin{array}{l}0.2402 \\
0.0785\end{array}$ \\
\hline Kinross Gold Corp & $\begin{array}{l}\text { Prod. } \\
\text { PPR }\end{array}$ & $\begin{array}{l}0.1476 \\
0.0780\end{array}$ & $\begin{array}{l}0.0470 \\
0.0460\end{array}$ & $\begin{array}{l}0.0750 \\
0.0361\end{array}$ & $\begin{array}{l}0.3560 \\
0.1786\end{array}$ & $\begin{array}{l}0.2471 \\
0.1071\end{array}$ \\
\hline Meridian Gold Inc $x \times v i]$ & $\begin{array}{l}\text { Prod. } \\
\text { PPR }\end{array}$ & $\begin{array}{l}0.0921 \\
0.0389 \\
\end{array}$ & $\begin{array}{l}0.1057 \\
0.0332\end{array}$ & $\begin{array}{l}0.0568 \\
0.0360\end{array}$ & $\begin{array}{l}0.4131 \\
0.2930\end{array}$ & $\begin{array}{l}0.1931 \\
0.1367 \\
\end{array}$ \\
\hline Newmont Mining Corp Eviif & $\begin{array}{l}\text { Prod. } \\
\text { PPR }\end{array}$ & $\begin{array}{l}0.0556 \\
0.0091\end{array}$ & $\begin{array}{l}0.0694 \\
0.0188\end{array}$ & $\begin{array}{l}0.0161 \\
0.0048\end{array}$ & $\begin{array}{l}0.1416 \\
0.0375\end{array}$ & $\begin{array}{l}0.0940 \\
0.0268 \\
\end{array}$ \\
\hline Placer Dome Inc. & $\begin{array}{l}\text { Prod. } \\
\text { PPR }\end{array}$ & $\begin{array}{l}0.6364 \\
0.1849\end{array}$ & $\begin{array}{l}0.6399 \\
0.1606\end{array}$ & $\begin{array}{l}0.5516 \\
0.1618\end{array}$ & $\begin{array}{l}1.0056 \\
0.1294\end{array}$ & $\begin{array}{l}0.8017 \\
0.1536\end{array}$ \\
\hline Richmont Mines Inc. & $\begin{array}{l}\text { Prod. } \\
\text { PPR }\end{array}$ & $\begin{array}{l}0.2278 \\
0.1145\end{array}$ & $\begin{array}{l}0.1507 \\
0.1027\end{array}$ & $\begin{array}{l}0.0316 \\
0.0227\end{array}$ & $\begin{array}{l}0.0299 \\
0.0287\end{array}$ & $\begin{array}{l}0.0400 \\
0.0232\end{array}$ \\
\hline TVX Gold Inc. ${ }^{\text {|x] }}$ & $\begin{array}{l}\text { Prod. } \\
\text { PPR }\end{array}$ & $\begin{array}{l}0.6828 \\
0.1615\end{array}$ & $\begin{array}{l}1.0269 \\
0.2666\end{array}$ & $\begin{array}{l}0.1994 \\
0.0247\end{array}$ & $\begin{array}{l}0.3800 \\
0.0366\end{array}$ & $\begin{array}{l}0.4480 \\
0.0329\end{array}$ \\
\hline Vista Gold & $\begin{array}{l}\text { Prod. } \\
\text { PPR }\end{array}$ & $\begin{array}{l}0.0000 \\
0.0000\end{array}$ & $\begin{array}{l}0.8491 \\
0.4699\end{array}$ & $\begin{array}{l}0.4762 \\
0.4149\end{array}$ & $\begin{array}{l}0.0000 \\
0.0000\end{array}$ & $\begin{array}{l}0.0000 \\
0.0000\end{array}$ \\
\hline
\end{tabular}

In order to "clean up" these raw hedging factors, stage one of the 2SLS regressed the fraction of 3-year future production hedged ${ }^{20}$ (as opposed to the fraction of proven and probable reserves hedged) against nineteen instrument variables. The results of this regression are presented below:

Regression Coefficients Where the Dependent Variable is Hedging Factor

\begin{tabular}{l|c|c}
\hline \multicolumn{2}{c}{ Adjusted $\mathrm{R}^{2}: 90.4 \%$} & Standard Error 21 \\
\hline Instrument Variable & Regression Coefficient & $(0.06168)$ \\
\hline Constant & -0.00848 & $\mathbf{( 0 . 0 0 1 2 8 2 )}$ \\
\hline Cash Balance (MM\$) & 0.003756 & $\mathbf{( 0 . 0 0 1 3 1 0 )}$ \\
\hline Current Assets (MM\$) & -0.005468 & $\mathbf{( 0 . 0 0 0 9 0 7 5 )}$ \\
\hline Long Term Debt (MM\$) & -0.0039857 & $\mathbf{( 0 . 0 0 2 4 9 8 )}$ \\
\hline EBITDA (MM\$) & 0.006094 & $\mathbf{( 0 . 0 4 3 6 1 )}$ \\
\hline Long (MM\$) & 0.005614 & $\mathbf{( 0 . 0 0 3 9 2 2 )}$ \\
\hline Current Portion of Long Term Debt (MM\$) & 0.17905 & $\mathbf{( 0 . 0 0 3 3 9 0 )}$ \\
\hline Debt Due in One Year (MM\$) & 0.012991 & $\mathbf{( 0 . 0 0 0 9 5 0 9 )}$ \\
\hline Debt - Convertible (MM\$) & -0.011847 & 0.0034090 \\
\hline
\end{tabular}

\footnotetext{
${ }^{20}$ Hedge ratios as a fraction of near-term production were used rather than as a fraction of proven $\&$ probable reserves because firms generally report their hedge positions (and presumably make their hedging decisions) in terms of production rather than reserves.

${ }^{21}$ Bold indicates statistical significance.
} 


\begin{tabular}{l|c|c}
\hline Debt - Subordinated (MM\$) & 0.20758 & $\mathbf{( 0 . 0 3 3 3 4 )}$ \\
\hline Debt - Notes (MM\$) & 0.006064 & $\mathbf{( 0 . 0 0 1 7 3 9 )}$ \\
\hline Debt - Debentures (MM\$) & 0.0040098 & $\mathbf{( 0 . 0 0 0 7 3 1 9 )}$ \\
\hline Long Term Debt - Other (MM\$) & 0.0039204 & $\mathbf{( 0 . 0 0 0 1 8 7 6 )}$ \\
\hline Net Income (MM\$) & -0.0006140 & $\mathbf{( 0 . 0 0 0 0 5 2 2 5 )}$ \\
\hline Total Current Executive Compensation (\$Thou.) & 0.00017273 & $\mathbf{( 0 . 0 0 0 4 1 4 1 )}$ \\
\hline Executive Restricted Stock Holdings (\$ value) & 0.0012156 & $\mathbf{( 0 . 0 0 0 1 8 9 8 )}$ \\
\hline Long Term Incentive Payouts & -0.0005693 & $(0.08778)$ \\
\hline Additional Business Line Dummy & -0.11918 & $(0.002309)$ \\
\hline Annual Revenues & -0.003723 & \\
\hline
\end{tabular}

This regression equation was then used to create expected hedge factors for each firm over the five years. These are presented below in Table 6 .

Table 6: Predicted Gold Hedge Portfolios as a Fraction of Three-Year Future Production

\begin{tabular}{|c|c|c|c|c|c|}
\hline \multirow[t]{2}{*}{ Firm } & \multicolumn{5}{|c|}{ Year } \\
\hline & 1996 & 1997 & 1998 & 1999 & 2000 \\
\hline Agnico-Eagle Mines LTD & -0.0557 & -0.0279 & -0.1979 & -0.0542 & 0.0295 \\
\hline Barrick Gold Corporation & 0.7593 & 0.9992 & 1.1658 & 0.8901 & 1.2628 \\
\hline Bema Gold Corporation & -0.2430 & -0.2401 & -0.1755 & -0.1120 & -0.1147 \\
\hline Cambior Inc. & 0.1317 & 0.2419 & 0.3871 & 0.5759 & 0.8120 \\
\hline Canyon Resources Corp. & -0.0671 & -0.0294 & -0.1036 & -0.0997 & -0.0824 \\
\hline Coeur D Alene Mines Corp. & 0.2600 & 0.1147 & 0.2933 & 0.3483 & 1.4954 \\
\hline Crystallex International Corp. & $\mathrm{N} / \mathrm{A}$ & -0.0272 & -0.0243 & -0.0195 & 0.0159 \\
\hline Dayton Mining Corporation & -0.0509 & -0.1037 & -0.1436 & -0.1337 & -0.1117 \\
\hline Echo Bay Mines LTD & 0.1532 & 0.4344 & 0.3847 & 0.1743 & 0.3239 \\
\hline Glamis Gold LTD & -0.0027 & 0.0117 & 0.0575 & 0.0421 & 0.1296 \\
\hline Goldcorp Inc. & -0.0639 & -0.0564 & -0.0453 & -0.1052 & -0.0540 \\
\hline Hecla Mining Co. & 0.0812 & 0.0830 & 0.1315 & 0.7994 & 0.5219 \\
\hline Homestake Mining & 0.0952 & 0.1209 & 0.2017 & 0.1863 & 0.2199 \\
\hline Kinross Gold Corp. & -0.3439 & -0.2926 & 0.7961 & 0.9560 & -0.0809 \\
\hline Meridian Gold Inc. & -0.1620 & -0.1726 & -0.0602 & -0.0069 & 0.0123 \\
\hline Newmont Mining Corp & -0.0018 & 0.1378 & 0.0992 & 0.0643 & 0.0901 \\
\hline Placer Dome Inc. & 0.6600 & 0.7694 & 0.5846 & 0.9296 & 0.6764 \\
\hline Richmont Mines Inc. & $N / A$ & 0.0409 & 0.0208 & -0.0041 & -0.0051 \\
\hline
\end{tabular}




\begin{tabular}{l|l|l|l|l|l}
\hline TVX Gold Inc. & 0.2712 & 0.0225 & 0.0055 & -0.2535 & -0.0294 \\
\hline Vista Gold & -0.0956 & 0.1222 & -0.0178 & -0.0055 & -0.0178 \\
\hline
\end{tabular}

Finally, the daily Stock File Index alphas were regressed against these new hedging factors along with the weekly volatility of stock returns and the yearly dummy variables. The results of this regression are presented below, along with the standard error of each coefficient in parentheses with statistical significance represented by bold.

Regression Coefficients Where the Dependent Variable is SFI Daily Alpha

\begin{tabular}{c|cccccc}
\hline $\begin{array}{c}\text { Adjusted } \\
\mathbf{R}^{2}(\%)\end{array}$ & Constant & $\begin{array}{c}\text { Hedging } \\
\text { Factor }\end{array}$ & $\begin{array}{c}\text { Year 1 } \\
\text { Dummy }\end{array}$ & $\begin{array}{c}\text { Year 2 } \\
\text { Dummy }\end{array}$ & $\begin{array}{c}\text { Year 3 } \\
\text { Dummy }\end{array}$ & $\begin{array}{c}\text { Year 4 } \\
\text { Dummy }\end{array}$ \\
\hline \multirow{2}{*}{17.2} & 0.02931 & -0.19846 & 0.0708 & -0.2372 & 0.0815 & 0.2190 \\
& $(0.07566)$ & $(\mathbf{0 . 0 9 0 5 4 )}$ & $(0.1060)$ & $(\mathbf{0 . 1 0 2 8})$ & $(0.1022)$ & $(\mathbf{0 . 1 0 2 0})$ \\
\hline
\end{tabular}

Based on the standard error of the hedging factor coefficient in the regression above, there appears to be a statistically significant negative correlation between hedging and alpha.

The final test performed in the study was to examine the relationship between hedging and stock price volatility. After all, the reduction of volatility is commonly considered an effect, or benefit, of hedging. In order to test this commonly held belief, I regressed the weekly volatility of the stock price against the predicted hedging factor and the yearly dummy variables. The results of this regression are presented below.

Regression Coefficients Where the Dependent Variable is Weekly Stock Price Volatility

\begin{tabular}{c|cccccc}
\hline $\begin{array}{c}\text { Adjusted } \\
\mathbf{R}^{2}(\%)\end{array}$ & Constant & $\begin{array}{c}\text { Hedging } \\
\text { Factor }\end{array}$ & $\begin{array}{c}\text { Year 1 } \\
\text { Dummy }\end{array}$ & $\begin{array}{c}\text { Year 2 } \\
\text { Dummy }\end{array}$ & $\begin{array}{c}\text { Year 3 } \\
\text { Dummy }\end{array}$ & $\begin{array}{c}\text { Year 4 } \\
\text { Dummy }\end{array}$ \\
\hline \multirow{2}{*}{16.0} & 0.10893 & -0.04271 & -0.05051 & -0.03384 & 0.03433 & 0.01041 \\
& $(\mathbf{0 . 0 1 5 5 1 )}$ & $(\mathbf{0 . 0 1 8 5 6 )}$ & $\mathbf{( 0 . 0 2 1 7 3 )}$ & $(0.02107)$ & $(0.02096)$ & $(0.02091)$ \\
\hline
\end{tabular}

Based on the standard error of the hedging factor in the regression above, there appears to be a statistically significant negative correlation between hedging and stock price volatility. This confirms the hypothesis that hedging reduces stock price volatility. 


\section{CONCLUSIONS}

The strong correlation between volatility and alpha suggests that the market indeed views gold firms as real options. The regression of daily alpha against the weekly volatility of stock returns resulted in a coefficient for the volatility of 3.57 and a T-statistic of 10.36. This supports the original hypothesis that investors value volatility when it comes to gold mining stocks.

There also appears to be a statistically significant correlation between the extent of gold hedging and the performance of the firm's stock price as measured by the regression alpha. The 2SLS regression that includes the hedging factor and the yearly dummy variables resulted in a Tstatistic of -2.19 for the annual hedging factor. The coefficient of -0.1985 indicates that the more management hedges gold price risk with gold derivatives, the worse it is for the return of their firm's stock as measured by the regression alpha. This is a significant finding, for it implies that gold mining firms that aggressively hedge gold price risk are not maximizing shareholder value. These results also provide empirical ammunition to the argument against hedging in the gold mining industry.

Furthermore, the regression linking hedging with volatility yielded a similar statistically significant relationship between the two. This follows our intuition, since one of the primary motivations for hedging in general is the reduction of volatility. Of course, the reduction of volatility in cash flows may not translate into a reduction in volatility of the stock price. In any case, it appears that while Barrick's hedging efforts make the firm's revenues more predictable, and may lower risk, this is counter to a shareholder wealth maximization strategy in the gold mining industry. Indeed, these results suggest that investors actually place a premium on more risk for gold mining firms. 
Decisions regarding risk management practices are clearly influenced by a number of factors, not the least of which relate to managers' efforts to maximize their own utility 22 One could argue that an effective risk management strategy can help to smooth earnings. But the results of this study indicate that even if this is true, overly aggressive risk management may not maximize value for firm owners. This suggests that decisions regarding risk management are not prompted by a desire to maximize shareholder wealth, but by other factors $\frac{\mathrm{xxiii}}{\text {. }}$

Although these results may hold for the North American gold mining industry over the period studied, additional research should be performed to determine if they hold in other industries. Investors in those other industries may apply a premium to the value of risk reduction through hedging (e.g. if volatility of cash flows is strictly frowned upon). As for the North American gold mining industry, these results indicate that risk reduction through hedging is of limited value to shareholders who are primarily interested in wealth maximization.

\footnotetext{
${ }^{22}$ In his article published in the Journal of Finance, 1996, Peter Tufano finds that management's hedging practices are largely influenced by the form of compensation they receive (e.g. stock versus options).
} 


\section{REFERENCES}

i "Bugs", The Economist, 10/14/1999

ii "Ashanti - the full story”, Emmanuelle Moors De Giorgio, African Business, 12/01/1999

iii "The great black hope", The Economist, 11/11/1999

${ }^{\text {iv }}$ Peter Tufano, "Who Manages Risk? An Empirical Examination of Risk Management Practices in the Gold Mining Industry", The Journal of Finance, September 1996

${ }^{v}$ Peter Tufano, "The Determinants of Stock Price Exposure: Financial Engineering and the Gold Mining Industry", The Journal of Finance, June 1998

${ }^{v i}$ Peter Tufano, The Determinants of Stock Price Exposure: Financial Engineering and the Gold Mining Industry, The Journal of Finance, June 1998

vii Barrick 2000 Annual Report

viii Goldcorp 2000 Annual Report

ix John Hathaway, "The Folly of Hedging”, The Tocqueville Funds, May 2000.

${ }^{x}$ Shaheen Pasha, "Precious Mettle: Tocqueville Gold Fund Braved 'Despised' Sector and Thrived," The Wall Street Journal, March 15, 2002

${ }^{x i}$ Source: Tocqueville Funds website

${ }^{x i i}$ William H. Greene, Econometric Analysis, Third Edition

xiii Source: Agnico-Eagle Mines annual reports 1996 - 2000

${ }^{\text {xiv }}$ Source: Barrick Gold annual reports 1996 - 2000

${ }^{x v}$ Source: Bema Gold annual reports 1996 - 2000

${ }^{x v i}$ Source: Cambior annual reports 1996 - 2000

${ }^{x v i i}$ Source: Canyon Resources annual reports 1996 - 2000

xviii Source: Coeur D Alene Mines annual reports 1996 - 2000

${ }^{x i x}$ Source: Crystallex International annual reports 1996 - 2000

${ }^{x x}$ Source: Dayton Mining annual reports 1996 - 2000

${ }^{x x i}$ Source: Echo Bay Mines annual reports 1996 - 2000

xxii Source: Glamis Gold annual reports 1996 - 2000

xxiii Source: Goldcorp annual reports 1996 - 2000

${ }^{x x i v}$ Source: Hecla Mining annual reports 1996 - 2000

${ }^{\mathrm{xxv}}$ Source: Homestake Mining annual reports $1996-2000$

${ }^{\text {xxvi }}$ Source: Kinross Gold annual reports 1996 - 2000

xxvii Source: Meridian Gold annual reports $1996-2000$

xxviii Source: Newmont Mining annual reports 1996 - 2000

${ }^{\text {xxix }}$ Source: Placer Dome annual reports 1996 - 2000

${ }^{\mathrm{xxx}}$ Source: Richmont Mines annual reports $1996-2000$

${ }^{x x x i}$ Source: TVX Gold annual reports $1996-2000$

xxxii Source: Vista Gold annual reports $1996-2000$

xxxiii Henry T. C. Hu, "Behind the Corporate Hedge: Information and the Limits of 'Shareholder Wealth Maximization"”, Bank of America Journal of Applied Corporate Finance, 1996 